\title{
MODELLING THE IMPACT OF INVESTMENTS ON ENERGY INTENSITY IN THE POLISH STEEL INDUSTRY AS A STEP TOWARDS INDUSTRY 4.0
}

\author{
${ }^{1}$ Bożena GAJDZIK \\ ${ }^{1}$ Silesian University of Technology, Gliwice, Poland, EU, bozena.gajdzik@polsl.pl
}

https://doi.org/10.37904/metal.2020.3663

\begin{abstract}
The investments affect the development of enterprises. In the perspective of Industry 4.0, if there were no impact of the COVID-19 pandemic on economies, enterprises would continue to realize strong investment strategies. Until March 2020, steel enterprises in Poland invested in new technologies, increasing efficiency in steel production. Automation of production and automation of the storage in combination with IT technology and the Internet of Things change the steel industry in Poland. The combination of operational technology (OT) with information technology (IT) is an opportunity for steel industries around the word. One of the field of changes is energy management in steel production. Energy reduction can be achieved through active monitoring of energy consumption and an intelligent energy management system used in steel production. Realized investments until the end of 2019 in the Polish steel industry (the value of investments/ PLN million) and the energy intensity in the steel production (toe/tonne of steel) in Poland were used to build econometric models. The time series used to build econometric models covered the period from 2000 to 2019. The aim of the research was to determine whether the steel industry in Poland saves energy as investment increases, with a particular focus on the trend towards Industry 4.0 in recent years.
\end{abstract}

Keywords: Steel industry, Poland, investment, energy intensity, econometric model

\section{INTRODUCTION}

Analysis of energy intensity is important in business management. Reducing environmental pollution and saving resources are key challenges in today's economy. On the way to sustainability, more and more enterprises are trying to use energy more efficiently. Energy efficiency reduces gas emissions and reduces production costs in the sustainability of the company. Energy efficiency is the ratio of the obtained results: goods and services to consumed energy in analyzed period. In the steel industry, energy is consumed per tonne of steel. EEI - Energy Efficiency Indicator informs about the decrease in energy consumption per unit of the product. Energy efficiency is steel industry toward Industry 4.0 is an important topic and new subject of research for scientists. Recently, this topic has been published by the authors: Wolniak et al. [1], Florens et al. [2], Johansson [3]. Energy efficiency in the Industry 4.0 can be realized through IT- integration of the production level with the planning level and further on to customers and suppliers (supply-chains). This IT integration is realized by cyber-physical-systems, the whole scenario is (in Germany) known as 'Industry 4.0' for some years now [4]. Klaus Schwab [5], founder and president of the World Economic Forum, the best known platform for the exchange of ideas and views, published a book entitled The Fourth Industrial Revolution, (2016), in which he points out the new changes in industry, economy, and society. The key pillars of Industry 4.0 are: loT, big data, cloud computing, advanced simulation, autonomous systems, universal integration, augmented reality, additive manufacture and cyber security. The pillars of Industry 4.0 are described in publications: Hermann et al. [6], Erboz [7], Saniuk et al. [8]. Industry 4.0 (until the Covid-19 crisis) was heavily promoted by politicians, scientists and global capital. The changes that led to Industry 4.0 appeared in recognized companies in such industries as: automotive, clothing, shoe production and home appliances. The first initiatives also appeared in the steel industry in Poland. Steelworks in Poland use mainly rather simple automated systems in steel 
production. Automation and modern Industrial Communication Technologies are used on selected production sections. The systems are controlling, monitoring and interacting processes in steel production. The work of blast furnaces is supervised by IT systems. The equipment in steel mills and rolling mills is partly or fully automatic. Huge progress has been made in the field of machine maintenance and management to implement Total Productive Maintenance - TPM [9]. Besides steel production in Poland, the first fully automated metallurgical warehouses are created in the southern regions in Poland. According to the PwC report [10], the metallurgical sector (respondents' opinions) until March 2020 spends around 4\% of annual revenues on new investments, while expecting a $3.2 \%$ decrease in costs. In a new reality - the crisis caused by the exclusion of economies due to Covid-19 - the steel works will reduce investment expenditure. From March 2020, demand for steel is declining. This will continue throughout 2020. In 2020 worldsteel forecasts that steel demand will contract by $6.4 \%$ due to the COVID-19 crisis. Steel demand in the developed economies is expected to decline by $17.1 \%$ in 2020. In developing countries steel demand (excluding China - Chinese steel demand is expected to increase by $1.0 \%$ in 2020) is expected to fall by $11.6 \%$ in 2020 . EU steel demand suffered a contraction of $5.6 \%$ in 2019 due to the sustained manufacturing recession [11]. In Poland, in March $2020,640,000$ tonnes of crude steel were produced, 30\% decrease from March 2019. In the period JanuaryMarch 2020, steel production amounted to 2 thousand tonnes of crude steel (decrease steel production compared to the previous year was 19\%) [12]. Investments have been stopped in recent months. The topic of the study is an analysis of the correlation between investment expenditures in the Polish steel industry (sector of steel production) and energy consumption during steel production. The aim of the analysis is to determine whether energy savings are achieved during steel production in the steel industry in Poland as the value of the investment increases. The value of the investments (PLN million) - source of data: Statistics Poland - has been made real over time taking into account inflation every year. Energy intensity is expressed in the toe/tonne of steel. The time limit of the analysis is the period from 2000 to 2019. The result of the analysis are econometric models. Two models are presented in the paper: linear model and exponential model with trend.

\section{ENERGY INTENSITY IN STEEL INDUSTRY IN POLAND IN THE PERIOD 2000-2019}

Between 2000 and 2019, the steel industry in Poland produced an average of $9.130 \mathrm{Mt}$ of steel per year. Efficiency per employee was 587.8 tonnes of steel. In the trend of steel production in Poland in the analyzed time series $(N=20)$ there were periodic fluctuations (seasonal fluctuations) - Figure 1. Since 2003, companies in the sector have been using two production processes: BOF (Basic Oxygen Furnace) and EAF (Electric Arc Furnace) because OHF technology (Open Hearth Furnaces - the Siemens-Martin process) was definitively

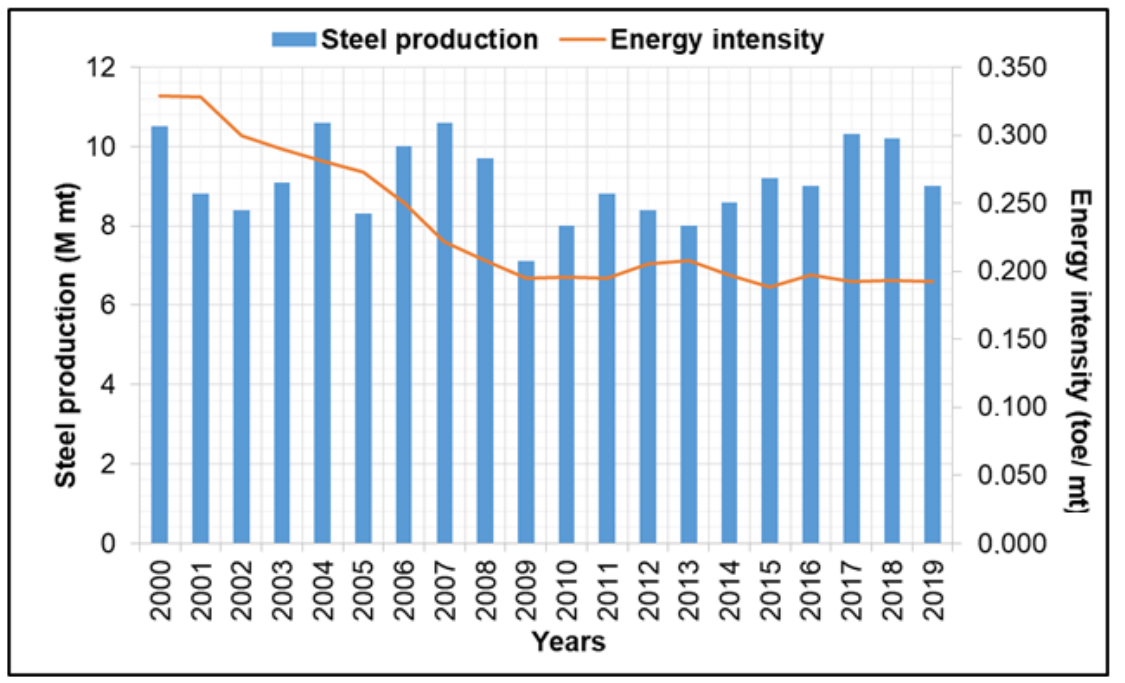

Figure 1 Steel production and energy intensity in Poland [13] discontinued in 2002). In the period from 2000 to 2019 the average annual BOF production was $5.200 \mathrm{Mt}$, EAF $3.880 \mathrm{Mt}$ of steel. Over the same period, the energy intensity was 0.2320 toe/tonne of steel. The energy intensity in Poland during the analysis period was lower than the average energy intensity in the EU. The average energy consumption in the EU was 0.3120 toe/tonne - Figure 2 . Presented current energy consumption is an introduction to further analysis. Data on energy consumption in the Polish steel 
industry are used to build econometric models (variable $y$ in models) and the investment value in steel industry in Poland in the period from 2000 to 2019 is the variable $x$ in the models - Figure 3.

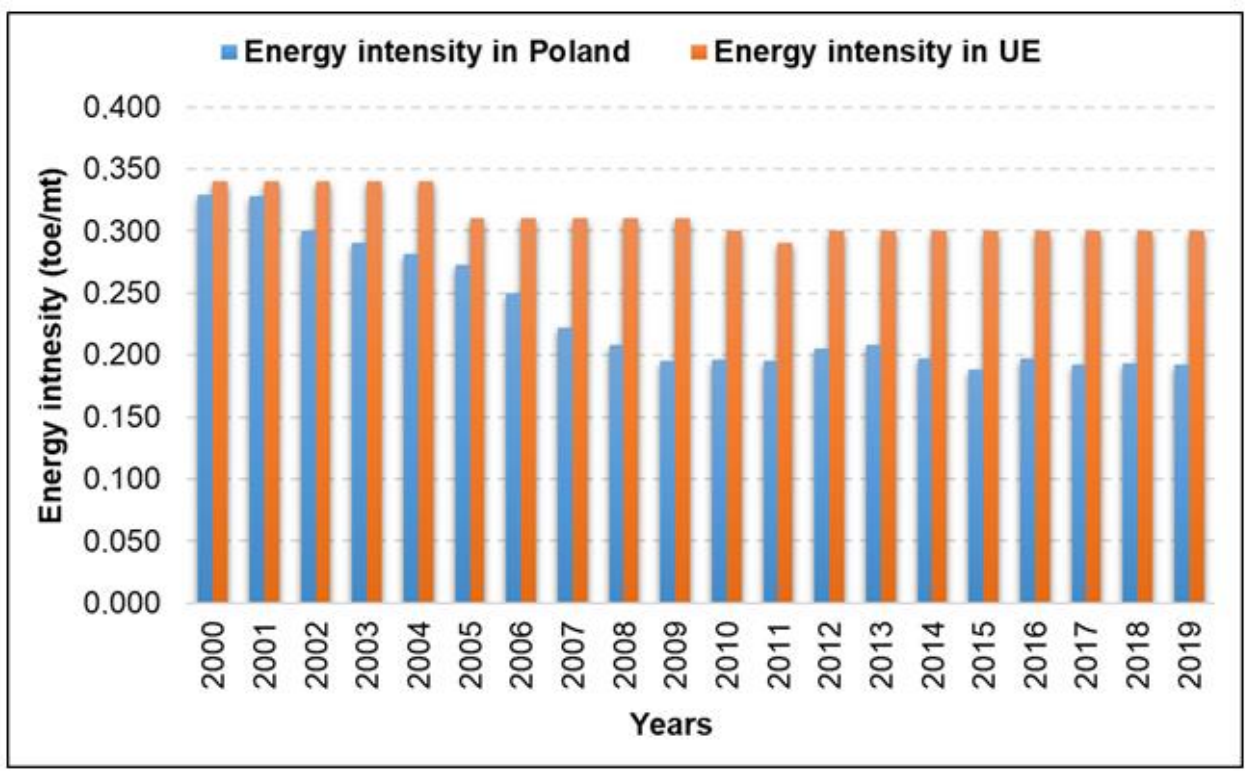

Figure 2 Energy intensity in steel industry in Poland and in the EU [13-14]

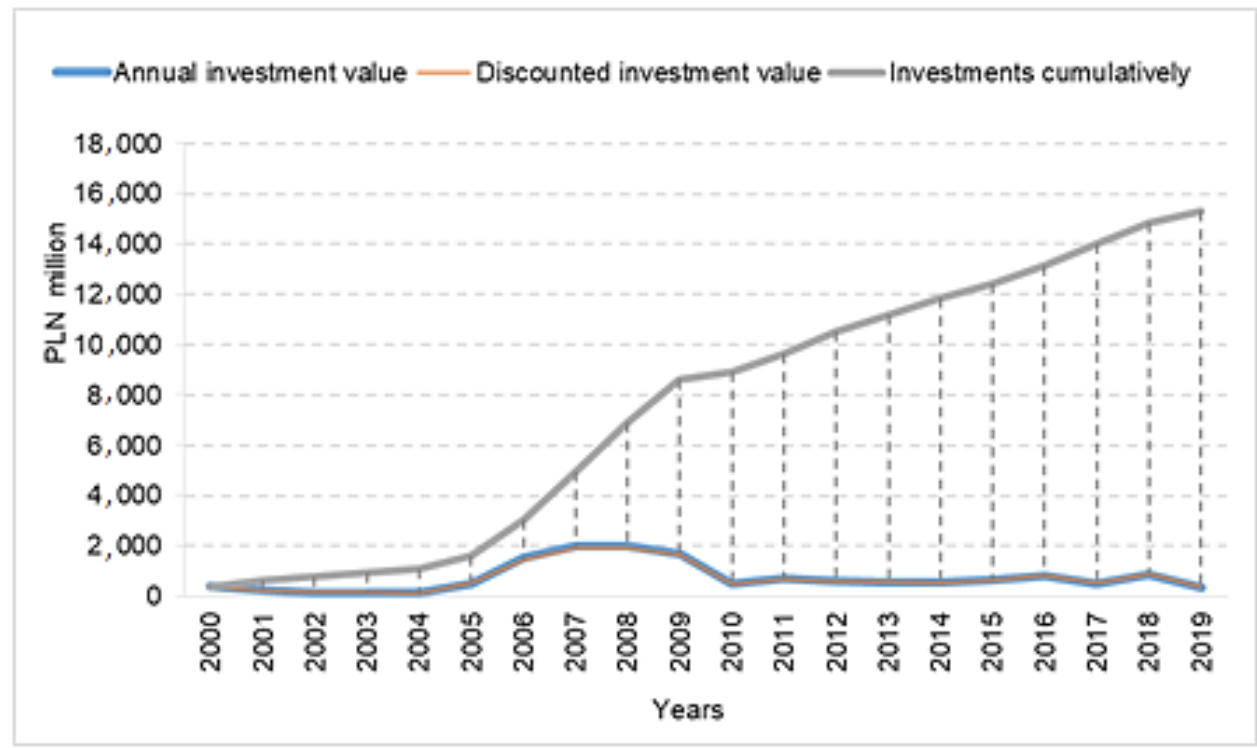

Figure 3 Investment value in Polish steel industry [15]

\section{METHODOLODY AND USED EMPIRICAL DATA}

The following steps have been performed in the analysis:

1) Obtaining empirical data

2) Determining Pearson's correlation coefficient

3) Building econometric models and their presentation

The analysis of the energy intensity according to the value of investments was carried out on the basis of empirical data. Used data is shown in Table 1. 
Table 1 Empirical data used in the building of econometric models [own study based on 13,15]

\begin{tabular}{|l|c|c|c|c|}
\hline No. & Years & $\begin{array}{c}\text { Discounted Investment } \\
\text { Value } \\
\text { (PLN million) }\end{array}$ & $\begin{array}{c}\text { Cumulative Investion Value } \\
\text { (PLN million) }\end{array}$ & $\begin{array}{c}\text { Energy intensity } \\
\text { (toe/tonne of steel } \\
\text { production) }\end{array}$ \\
\hline 1. & 2000 & 379 & 379 & 0.3290 \\
\hline 2. & 2001 & 226 & 618 & 0.3280 \\
\hline 3. & 2002 & 159 & 784 & 0.3000 \\
\hline 4. & 2003 & 164 & 928 & 0.2900 \\
\hline 5. & 2004 & 134 & 1,074 & 0.2810 \\
\hline 6. & 2005 & 523 & 1,609 & 0.2730 \\
\hline 7. & 2006 & 1,474 & 3,060 & 0.2500 \\
\hline 8. & 2007 & 1,940 & 4,950 & 0.2220 \\
\hline 9. & 2008 & 1,927 & 6,910 & 0.2080 \\
\hline 10. & 2009 & 1,651 & 8,622 & 0.1950 \\
\hline 11. & 2010 & 464 & 8,945 & 0.1960 \\
\hline 12. & 2011 & 674 & 9,671 & 0.1950 \\
\hline 13. & 2012 & 597 & 10,536 & 0.2050 \\
\hline 14. & 2013 & 575 & 11,206 & 0.2080 \\
\hline 15. & 2014 & 555 & 11,863 & 0.1970 \\
\hline 16. & 2015 & 650 & 12,406 & 0.1880 \\
\hline 17. & 2016 & 825 & 13,157 & 0.1970 \\
\hline 18. & 2017 & 541 & 14,041 & 0.1920 \\
\hline 19. & 2018 & 884 & 14,870 & 0.1935 \\
\hline 20. & 2019 & 358 & 15,331 & \\
\hline
\end{tabular}

In the first step of modelling, Pearson's correlation coefficient $(r)$ was used. Pearson's correlation coefficient $r$ for the impact of investments on the energy intensity was -0.90169 . Pearson's correlation $r=-0.9$ means that there is a strong negative correlation between investments and energy consumption in the Polish steel sector. The correlation result between the variables tested: $y$ - energy consumption in steel production (steel energu intenisty), $x$ - investments in steel sketor, allowed to realize the next step of research, which was the construction of econometric models. In the paper, two models were presented: linear and non-linear.

\section{PRESENTATION OF OBTAINED ECONOMETRIC MODELS}

Obtained models:

1) Linear model (formula 1)

$y=-8.589 \cdot 10^{-6} x+0.295$

where:

$$
\begin{aligned}
& y \text { - steel energy intensity (toe/ } 1 \text { tonne) } \\
& x \text {-investments (PLN million) }
\end{aligned}
$$

Cooeficient determinantion for this model was $R^{2}=0.8281$. Cooeficient determinantion is high, which means the model is good fitted. Obtained model informs that realized investments in the steel industry in Poland in 
the period from 2000 to 2019 affect energy consumption in steel production in the sector. Figure 4 shows trends for real and estimated steel energy intensity in Polish steel industry.

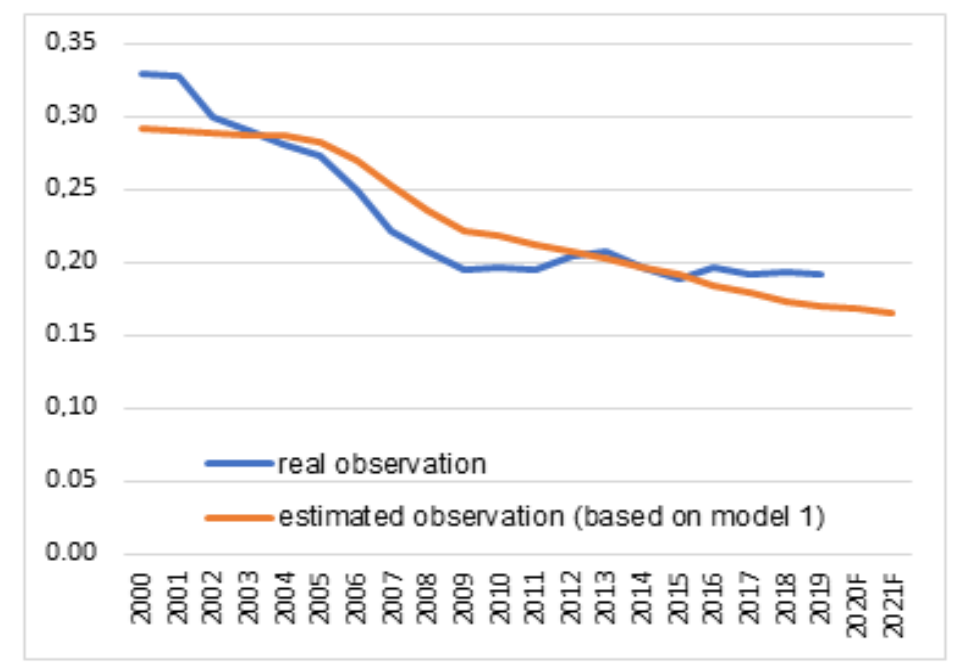

Figure 4 Model 1: steel energy intensity in Poland [own study]

2) Exponential model with trend (formula 2)

$y=-1.2 \cdot 10^{-5} x-0.019 t+0.001 t^{2}+0.360$

where:

$$
\begin{aligned}
& y \text { - steel energy intensity (toe/1tonne] } \\
& x \text { - investments (PLN million) } \\
& t \text { - time (years) }
\end{aligned}
$$

This model is better than first model $\left(R^{2}=0.9713\right)$, the model explains $97 \%$ variability energy intensity through investments in steel production in Poland. The model is statistically significant. Obtained model informs that increasing investments in the steel industry in Poland by a unit in the following year will result in a decrease in unit energy consumption of $-1.2 \cdot 10^{\wedge}-5$ toe/tonne of steel for other unchanged factors. In each following year energy saving will be of 0.019 for other unchanged factors. Figure 5 shows trends for real and estimated steel energy intensity in Polish steel industry.

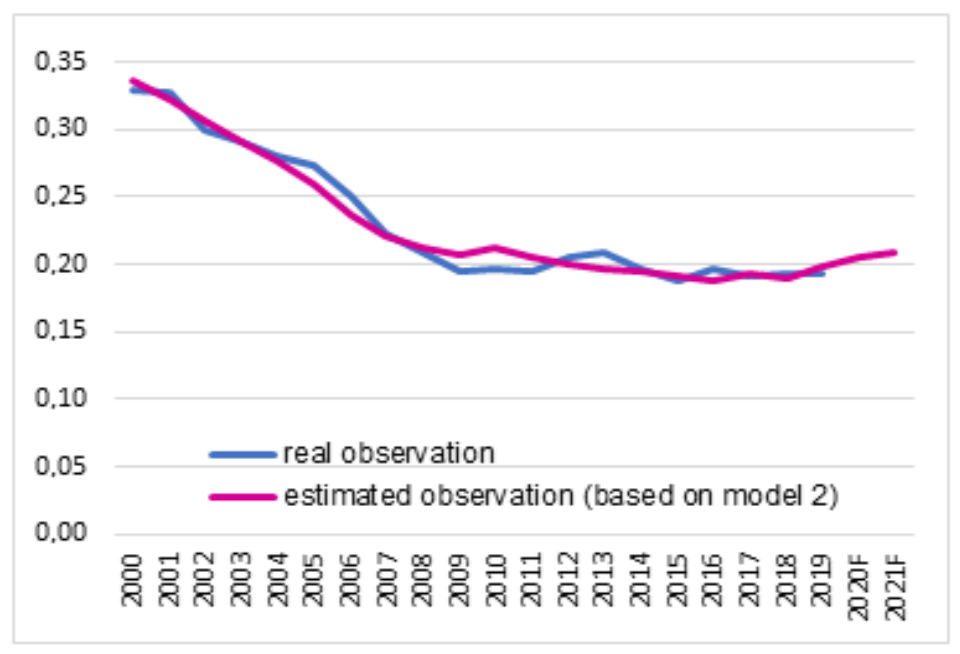

Figure 5 Model 2: steel energy intensity in Poland [own study] 


\section{CONCLUSION}

The obtained models show that the increase in investment expenditures contributes to the decrease in energy consumption in the Polish steel sector. Based on the obtained models, it can be assumed that in the following years the increase in investment expenditures in the steel industry in Poland will affect energy savings. The situation of reducing steel production, together with the decrease in steel demand during the Covid-19 pandemi, has a negative impact on the conclusion. Economic crisis disrupts steel production trend (such situation was in period 2009-2010). Strong fluctuations in the trend of steel production make it difficult to perform the econometric analyses and build statistic models. The decline in steel production during the Covid19 crisis can be expected to reduce energy consumption in the steel industry, but unfortunately also to a decline in investment expenditures. The expansion strategies realized until March 2020 in the steel industry in Poland are being replaced by cost-cutting strategies druring the period of Covid-19.

\section{ACKNOWLEDGEMENTS}

\section{Silesian University of Technology, Poland (Faculty of Materials Engineering), supported this work as a part of statutory research BK-261/RM4/2020 (11/040/BK_20/0018)}

\section{REFERENCES}

[1] WOLNIAK, R., SANIUK, S., GRABOWSKA S., GAJDZIK, B. Identification of Energy Efficiency Trends in the Context of the Development of Industry 4.0 Using the Polish Steel Sector as an Example. Energies.2020, vol. 13, issu. 11, 2867, pp.1-16; doi:10.3390/en13112867, https://www.mdpi.com/1996-1073/13/11/2867/htm

[2] FLORENS, F., RÜBBELKE, D., VÖGELE, S. An analysis of the economic determinants of energy efficiency in the European iron and steel industry. J. Clean. Prod. 2015, vol. 104, pp. 250-263.

[3] JOHANSSON, M. Improved energy efficiency within the Swedish steel industry-The importance of energy management and networking. Energy Effic. 2015, vol. 8, pp. 713-744.

[4] KAGERMANN, H., J. HELBIG, A. HELLINGER, WAHLSTER. W.. Recommendations for Implementing the Strategic Initiative Industry 4.0: Securing the Future of German Manufacturing Industry. Final Report of the Industry 4.0 Working Group. Forschungsunion, 2013.

[5] SCHWAB, K. The Fourth Industrial Revolution. World Economic Forum, Geneva, Switzerland, 2016.

[6] HERMANN, M., PENTEK, T., OTTO, B. Design Principles for Industrie 4.0 Scenarios, A Literature Review. "Working Paper", Technische Universität Dortmund, 2015.

[7] ERBOZ G. How to define industry 4.0: The Main Pillars of Industry 4.0, 2017.

[8] SANIUK, S., GRABOWSKA, S., GAJDZIK, B. Social Expectations and Market Changes in the Context of Developing the Industry 4.0 Concept. Sustainability. 2020, vol. 12, no. 1362; doi:10.3390/su12041362

[9] GAJDZIK, B. Autonomous and professional maintenance in metallurgical enterprises as activities within Total Productive Maintenance. Metalurgija. 2014, vol. 53, no. 1, pp. 269-272.

[10] Industry 4.0, PwC [online]. Available from: https://www.pwc.pl/pl/pdf/przemysl-4-0-raport.pdf

[11] PRESS RELEASE - Worldsteel Short Range Outlook 4th June 2020. Brussels, Belgium.

[12] SYTUACJA W PRZEMYŚLE STALOWYM I W GOSPODARCE NARODOWEJ POPYT, PODAŻ, PROGNOZY. March 2020, Polish Steel Association, Katowice, Poland.

[13] Polish Steel Industry, reports of Polish Steel Association, Katowice, Poland.

[14] Statistical reports of Eurostat https://ec.europa.eu/eurostat/publications/statistical-reports

[15] Statistical Offices: https://stat.gov.pl/en/topics/industry-construction-fixed-assets/industry/archive 